\title{
THE PROBLEM OF CASH SURRENDER VALUES AND CASH LOANS
}

\author{
BY JOHN B. LUNGER, \\ Vice-President, The Equitable Life Assurance Society.

\section{SURRENDER VALUES}

The granting of cash surrender values and loans from reserves is developing into a serious problem for life insurance companies.

Originally the surrender value of a lapsed or forfeited policy was granted in the form of paid-up or extended insurance. It was thus limited on the theory that the policy was not a banking contract, that the retiring policyholder having made a contract for insurance, his reserve should only be applied in the form of insurance.

In time the abandonment of this theory was forced by competition and the practice of paying surrender values in cash became common. In 1906 this privilege was made a statutory requirement in the new Insurance Law of the State of New York. For the ten years following 1905 , the proportion of cash payments to the reserves on the policies surrendered increased 42 per cent.

The right of the deserting policyholder to withdraw the reserve on his policy minus a reasonable surrender charge cannot be questioned. The weakness of the present method of expressing this right lies in the fact that the privilege of taking cash instead of paid-up or extended insurance reverses the original purpose of the contract and often encourages needless lapsing. This privilege has tempted many policyholders to unnecessarily surrender their policies to secure ready cash which has resulted in the loss of a great volume of valuable insurance protection.

While the return to the original practice of giving paid-up or extended insurance in place of cash for surrendered policies may be classed among the impossibilities, there is a phase of the application of the present plan which demands, and it is hoped may receive, remedial action, namely, the question of the surrender charge.

The New York Laws of 1906, under which the bulk of American life insurance is written, and which have been copied in many states, provide that the entire reserve less one-fifth or the sum of two and 
fifty one-hundredth dollars for each one hundred dollars of insurance shall, upon demand not later than three months after the date of lapse or surrender of the policy, be applied as a surrender value as agreed upon in the policy. While this law defines the minimum of the reserve which shall be paid or applied to surrender values, which consist of cash values, paid-up insurance or extended insurance, in practice this minimum is exceeded. Nearly every company allows the entire reserve as a surrender value in cash, or its equivalent in paid-up insurance, after the tenth year of insurance, and deducts less than the surrender charge allowed by the law in the early policy years. It is perhaps in the increase of cash surrender values and in reducing the intervals or periods at which they may be taken that the competitive concessions found their most questionable expression during the period between 1880 and 1905 . In 1880 very few companies guaranteed cash values at all. Later certain companies adopted values payable at the end of each fifth year of insurance, but by degrees, under the force of competition, annual values became general and then the amounts of the values were gradually increased until guarantees equal to the full reserve were reached and competition could go no further. The effect of this was to emphasize the importance of the individual policy-displacing the principle which regarded the interests of the whole body of the insured to be paramount to those of the individual.

The old-fashioned notion was that each retiring policyholdereach deserter from the ranks as it were-should pay a proper surrender charge as a quid pro quo for the loss sustained by the whole body of policyholders through his retirement. While the 1906 law allows a surrender charge there is nothing in it forbidding the companies to waive such charge, hence we find that certain companies are paying the full reserve after the policy has been in force for only a few years; in two or three companies after only three years. In other words, the law protects the deserter by stipulating that he must be paid certain minimum values but fails utterly to act in the interests of the whole body of policyholders by prohibiting larger payments to the deserter than he is in equity entitled to receive.

Herein is the defect in the law. It should define a surrender charge adjusted to the kind and age of the policy; and then provide that no company shall guarantee in its policies, or pay in practice, a larger cash value than the reserve less such surrender charge. 
If a surrender charge should be imposed in all cases when cash is taken, the amount of such charge could be used to replace the retiring policyholder without casting the burden of cost on the persistent policyholders. If need be it could be used as a compensation for a decline in values, unexpectedly high mortality, or other contingencies.

Undoubtedly the cash value privilege is a great help in times of emergency, and it must be conceded that sometimes it is very important to protect the insured and his family while the insured is living. But no policyholder should be permitted to retire and withdraw his entire equity in reserves, thereby transferring his share of any depreciation or other unfavorable contingency to those who remain.

\section{Policy Loans}

The policyholder's privilege of borrowing a portion of his reserves on the security of his insurance contract was also a development of competition, and like the giving of surrender values, the idea grew and the original privilege was extended until the plan became permanently fixed upon the business by being made a requirement of the law.

As originally intended, this privilege would have been a great service to the policyholder and to the companies as an attractive feature or inducement to insure, but, as in the case of surrender values, the loan privilege has been carried to extremes, the general practice now being to loan, as well as to pay as a cash value, the full reserve upon a policy after the tenth year of insurance.

The standard contract provisions required by Section 101 of the New York Laws requires in each contract a provision relating to policy loans which is described as follows:

A provision that after three full years' premiums have been paid, the company at any time, while the policy is in force, will advance, on proper assignment or pledge of the policy and on the sole security thereof, at a specified rate of interest, a sum equal to, or at the option of the owner of the policy less than the reserve at the end of the current policy year on the policy and on any dividend additions thereto, less a sum not more than $2 \frac{1}{2}$ percentum of the amount insured by the policy and of any dividend additions thereto; and that the company will deduct from such loan value any existing indebtedness on the policy and any unpaid balance of the premium for the current policy year, and may collect interest in advance on the loan to the end of the current policy year; which provision may further provide 
that such loan may be deferred for not exceeding six months after the application therefor is made. A company may, in lieu of the provision hereinabove permitted for the deduction from a loan on the policy of a sum not more than $2 \frac{1}{2}$ percentum of the amount insured by the policy and of any dividend additions thereto, insert in the policy a provision that one-fifth of the entire reserve may be deducted in case of a loan under the policy, or may provide therein that the deduction may be the said $2 \frac{1}{2}$ percentum or the one-fifth of the said entire reserve at the option of the company.

The primary purpose of this law, which fastens a banking function upon life insurance, was to enable the policyholder to have the use of his reserves in time of financial stress. It was believed that this would be of great value in preventing lapses by permitting the insured to apply his reserves to the payment of premiums when short of cash, and that the plan in general would prove an attractive one as an inducement to the taking of insurance.

These advantages are freely conceded, but experience has demonstrated that they have been largely neutralized by the disadvantages and the abuses which have resulted from the expansion of this loan privilege. These loans operate directly against the beneficiary by reducing the protection, for only a small per cent of the loans are repaid by the borrowers and the rest must be deducted from the claims at death or from surrender values. They also encourage lapsing by the additional burden placed upon the policyholder. Many borrowers, finding their protection reduced, their premiums remaining the same and an annual interest charge to pay, become discouraged and lapse or abandon their policies. An injustice is also done the remaining policyholders by the low withdrawal charge and the possible danger of a "run" on reserves in time of panic. Broadly speaking, the policy loan privilege discourages saving and encourages spending. This fact is emphasized by the extraordinary increase in the diversion of policy reserves from their original purpose during recent years.

The magnitude of the problem which has resulted from this unwisely extended privilege may be appreciated by a study of the following table which shows the extent to which these reserve funds have been withdrawn from the American "old line" companies since 1890: 


$\begin{array}{rrrc}\text { Year } & \text { Reserves } & \text { Policy Loans } & \begin{array}{r}\text { Ratio of Loans } \\ \text { To RESERVES }\end{array} \\ 1890 & \$ 669,963,688 & \$ 19,903,242 & 2.97 \% \\ 1895 & 980,248,946 & 35,524,530 & 3.62 \% \\ 1900 & 1,443,452,319 & 88,500,575 & 6.13 \% \\ 1905 & 2,295,289,818 & 225,568,149 & 9.83 \% \\ 1910 & 3,225,966,060 & 495,099,854 & 15.35 \% \\ 1915 & 4,362,255,809 & 779,158,909 & 17.86 \%\end{array}$

Those who borrow on their policies are not satisfied with small amounts. They are tempted to withdraw all the money they can get, and, having gotten it, they are tempted to spend it for pleasure or to risk it in business or speculative ventures. The result is that a temporary loan develops into a permanent obligation, and the idea of repaying it is abandoned. Consequently when death comes the widow finds that her life insurance has been materially reduced and then bitter disappointment and sometimes misery and hardship follow.

It is not surprising, therefore, that the practice of borrowing on policies has come to be known as borrowing from the widow and orphan. No concession ever granted to policyholders has operated so greatly to the disadvantage of beneficiaries. This is particularly true when the loans are taken with the assistance of the Change of Beneficiary Clause, whereby the wife of the insured is too frequently denied a knowledge of the transaction. In two companies, at least in the case of policies drawn in favor of the wife, unless the insured insists upon his privileges under the Change of Beneficiary Clause, an effort is made to obtain the wife's signature to the loan papers. It is surprising how often the mortage of a policy is thus avoided.

One class of loans-those taken out on policies issued for the protection of business ventures or for purely commercial purposesare justifiable; they are serving a purpose for which the contract was entered into. But one cannot view with equanimity the taking of loans on policies issued for family protection, and unfortunately the greater number of loans are taken on this class of policies.

If those who have it within their power to make and amend laws could know the disappointment incident to policy loans and the hardships which are often inflicted on the insured himself, they would find sufficient reason in these disappointments alone to amend this section so that loans would be mandatory only for the purpose 
of paying premiums, leaving the question of an additional loan to the judgment of the officers of the companies, but stipulating that the total loan shall in no case exceed the cash value which should be on a reduced basis.

In foreign countries where life insurance has been practiced longer than here underwriters have prudently abstained from following our lead with respect to maximum cash values, although they have adopted several of our American innovations. In a review of the cash surrender values offered by the English companies, it was found that in the case of thirty-nine the cash values range from 25 per cent to 50 per cent of the premiums paid. The values for all ordinary durations of insurance are very much below the reserves held under the policies. In general the values are fully 20 per cent lower than in this country.

The English companies also grant policy loans and the prospectuses of the companies show that the loans are limited to the cash surrender values, which as above stated, are always well within the reserves. The policy of one company contains a rather unique provision to the effect that in case the rate of discount in the Bank of England is 7 per cent or more at the time the cash value is applied for, the directors may either pay a reduced value or defer payment until the rate falls below 7 per cent. That the person who drafted this condition possesses amongst his other traits that of perspicacity is only too well evidenced by the present distressing war conditions on the other side of the sea.

In France the policies of the leading companies provide for cash values, but the amounts instead of being specified in the contracts are subject to the rules of the Board of Directors at the time of surrender. Excepting in the case of one company, the values at no time exceed 85 per cent of the reserves, closely following the English practice. Again in France, as in England, loans are made up to an amount not exceeding 95 per cent of the cash value. One of the French companies provides a check against declining values in securities by stipulating that in case French rentes are quoted below 90 the cash values may be reduced.

From this statement of foreign practice it will be seen that in granting cash values and policy loans, both the English and French companies are far more conservative than the American companies, avoiding extreme liberality and safeguarding the interests of their 
policyholders as a body by keeping their payments to those who borrow money or retire from the company fairly within the reserves.

Another point with respect to cash values and policy loans which we must consider is that the investments of the life insurance companies are made with regard to the maturity of the policy contracts and the continuance of the business under normal conditions. The two most common forms of investment, therefore, are mortgages and long-time bonds. When money is easy and there is an active investment market, it is possible to realize upon bonds, or to collect a part at least of the mortgages which mature. On the other hand, under unfavorable conditions these two classes of securities are anything but liquid. Consequently it follows that if unduly liberal cash values and policy loans are to continue to be a feature of policy contracts the life insurance companies will eventually be required to make short-time or call loans. These forms of investment are now practically denied to life insurance companies.

At present there are apparently only two ways by which the companies can protect themselves against the possibility of a long continued drain if one should occur in the years to come. One is by carrying large cash balances, which is obviously objectionable; and the other is by purchasing short-time bonds, or secured notes of which there are comparatively few in the market. And if life insurance should develop competition for this class of investments the price would be raised to such a point as to make the returns inadequate.

The question of the possible ultimate effect on investments of cash policy guarantees is one of the most important before us today, and especially as one of the uncontemplated effects of guarantees is to gradually convert each company, to the extent of its reserves, into a combination of a life insurance company and a savings bank.

It is difficult to make an estimate of the proportion of present reserves which are subject to cash demands, but it is a considerable percentage of the whole. As the old policies which do not provide for cash are becoming less in number each year, we may look forward to the time, perhaps only fifteen or twenty years hence, when nearly the entire reserves will be subject to demand payments unless the tenor of things is changed in the meantime.

The defects of the present situation are fundamental. Our cash 
values and loan values need to be brought down to the level that will not be an inducement to the easy forfeiture of the insurance but which will tend rather to permanence in the carrying of the policy. There is a body of opinion which believes that three or six months' notice of intention to borrow or to demand the cash value is a sufficient corrective, but as the defects are fundamental a three or six months' notice is but a superficial remedy. Faults which are basic and have within them the possibilities of becoming a menace cannot be cured by postponement.

With the.assistance of our state insurance officials and our legislative bodies, it appears entirely possible happily to compromise by legislative corrections so as to find the golden mean between the practices and benefits which obtained about thirty years ago, and those in vogue at the present time. 